\title{
Partial Purification of a Peroxisomal Polyamine Oxidase from Candida boidinii and its Role in Growth on Spermidine as Sole Nitrogen Source
}

\author{
By GEOFFREY W. HAYWOOD AND PETER J. LARGE* \\ Department of Biochemistry, University of Hull, Hull HU6 $7 R X, U K$
}

(Received 29 September 1983; revised 9 December 1983)

\begin{abstract}
Candida boidinii grows well on spermidine as sole nitrogen source, but poorly on spermine. Cells grown on spermidine, cadaverine, putrescine and 1,3-diaminopropane contained a polyamine oxidase which attacks spermine and spermidine at the secondary amino groups, forming putrescine and a product thought to be 3-aminopropionaldehyde. The enzyme was synthesized before growth began when $C$. boidinii that had been grown in medium containing glucose + ammonium was transferred to medium in which spermidine replaced ammonium. Other enzymes increasing in specific activity during this adaptation were catalase, benzylamine oxidase and NAD-dependent glutamate dehydrogenase. The polyamine oxidase was purified to $50 \%$ homogeneity, but was too unstable to obtain completely pure. It had a $\mathrm{pH}$ optimum of $10 \cdot 0$, and could be stabilized by addition of inert protein. It oxidized spermine, spermidine, $N^{1}$ acetylspermidine, $N$ - $n$-butylpropylamine, di- $n$-butylamine and di- $n$-hexylamine. It did not oxidize di-n-propylamine, diethylamine or $N^{1}, N^{8}$-diacetylspermidine. Apparent $K_{\mathrm{m}}$ values were determined for the active substrates. The enzyme was potently inhibited by quinacrine and by divalent cations. The stoicheiometry of the enzyme reaction was established using di- $n$ butylamine as substrate. The enzyme has a molecular weight in the range 80000 to 110000 . Putrescine (the oxidation product of spermidine) was not oxidized by cell-free extracts, but evidence of aminotransferase activity was found. The oxidation/transamination product of putrescine, 4-aminobutyraldehyde (1-pyrroline), was oxidized by extracts and a scheme is presented by which spermidine could be catabolized. Polyamine oxidase was shown to cosediment with NAD-dependent glycerol 3-phosphate dehydrogenase and catalase in sucrose gradients after mechanical breakage of spheroplasts, and is thus a peroxisomal enzyme. Polyamine oxidase was present in some other yeasts when grown on spermidine, $C$. nagoyaensis, Hansenula polymorpha and Trichosporon melibiosaceum, but absent from C. steatolytica, Pichia pastoris and Sporopachydermia cereana. These latter yeasts probably contained an enzyme resembling benzylamine/putrescine oxidase which attacks the primary amino groups of spermidine.
\end{abstract}

\section{INTRODUCTION}

Candida boidinii when grown on $n$-butylamine as sole nitrogen source produces two primaryamine oxidases, neither of which can oxidize the diamine putrescine (1,4-diaminobutane) nor the polyamines spermine (1,12-diamino-4,9-diazadodecane) and spermidine (1,8-diamino-4azaoctane)(Haywood \& Large, 1981). Other yeasts, e.g. Pichia pastoris, contain a primary-amine oxidase which can liberate ammonia from the primary amino groups of all three compounds (Green et al., 1983). It was thus of interest to attempt to grow C. boidinii on polyamines as nitrogen source in order to determine their mode of degradation. Candida boidinii turned out to grow well on spermidine and putrescine, but only slowly on spermine, and in this paper we attempt to identify the enzymes responsible for liberating the primary and secondary amino groups of spermine and spermidine in a form utilizable by the yeast. 


\section{METHODS}

Materials. 2-Aminobenzaldehyde was synthesized as described by Albrecht et al. (1962). 1-Pyrroline (4aminobutyraldehyde) was synthesized from DL-ornithine as described by Jakoby (1962). $N^{1}$-Acetylspermidine was prepared as described by Tabor et al. (1971) and purified on a Dowex 50-X8 ( $\mathrm{H}^{+}$form) column. It contained a trace $(0.5 \%)$ of spermidine. It was standardized using benzylamine/putrescine oxidase of Pichia pastoris. $N^{1}, N^{8}-$ Diacetylspermidine was isolated from the same reaction mixture, as described by Bolkenius \& Seiler (1981). $N-n-$ Butylpropylamine was obtained from K \& K Rare and Fine Chemicals (ICN Pharmaceuticals) via Kodak; di- $n$ butylamine, di-n-propylamine and 3-aminopropanol were from $\mathrm{BDH}$; and di-n-octylamine, 3,3iminobispropylamine and diethylenetriamine were from Aldrich Chemical Co., Gillingham, Dorset, UK. All other chemicals were obtained from Sigma or Fisons Scientific Apparatus. Benzylamine/putrescine oxidase was purified from Pichia pastoris as described by Green et al. (1983), and yeast aldehyde dehydrogenase, catalase and horseradish peroxidase were obtained from Sigma. Zymolyase 5000 (Kitamura et al., 1971) was obtained from Miles Laboratories, Stoke Poges, Bucks, UK.

Maintenance and growth of the organism. This has been described previously (Haywood \& Large, 1981). The carbon source was $55 \mathrm{~mm}$-glucose and the nitrogen sources were used at $30 \mathrm{~mm}$ (ammonia) or $5 \mathrm{~mm}$ (spermidine). Nitrogen sources in the experiment of Table 3 were $10 \mathrm{~mm}$.

Enzyme assays. Polyamine oxidase (EC 1.5.3.-) was assayed by two different methods. Spermine was used as substrate except where indicated. (a) Polarographic assay. Enzyme and $200 \mu \mathrm{mol}$ sodium borate buffer $\mathrm{pH} 10 \cdot 0$ were incubated in the chamber of a Rank oxygen electrode (Rank Instruments, Bottisham, Cambridge, UK) at $25^{\circ} \mathrm{C}$. The reaction was started by the addition of $10 \mu \mathrm{mol}$ spermine tetrahydrochloride. The reaction volume

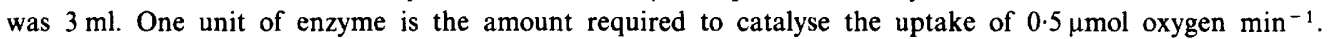
(b) Spectrophotometric assay. Enzyme, $200 \mu \mathrm{mol}$ sodium borate buffer $\mathrm{pH} 10 \cdot 0,2.5 \mu \mathrm{mol}$ of the sodium salt of ABTS and 16 units $\left(200 \mu \mathrm{g}\right.$ ) of horseradish peroxidase (total volume $3 \mathrm{ml}$ ) were incubated at $25^{\circ} \mathrm{C}$ in polystyrene cuvettes (light path $1 \mathrm{~cm}$ ). The reaction was started by addition of $10 \mu \mathrm{mol}$ spermine tetrahydrochloride and the increase in absorbance at $405 \mathrm{~nm}$ was followed against a blank containing all components except substrate (Haywood \& Large, 1981). One unit of enzyme is the amount required to catalyse the formation of ABTS radical cation at a rate of $1 \mu \mathrm{mol} \mathrm{min}{ }^{-1}$ under these conditions. An extinction coefficient of $18.41 \mathrm{mmol}^{-1} \mathrm{~cm}^{-1}$ was used (Werner et al., 1970).

Other oxidases were assayed in an analogous fashion (Haywood \& Large, 1981; Green et al., 1982, 1983). Diamine aminotransferase (EC 2.6.1.29) was assayed as described by Kim (1964). Catalase (EC 1.11.1.6) was assayed as described by Haywood \& Large (1981), cytochrome $c$ oxidase (EC 1.9.3.1) as described by Wharton \& Tzagoloff (1967), NADH dehydrogenase (EC 1.6.99.3) as described by Mackler (1967), NAD-linked glycerol-3phosphate dehydrogenase (EC 1.1.1.8) as described by Kawamoto et al. (1979), isocitrate dehydrogenase (EC 1.1.1.42) as described by Bergmeyer (1974), and NAD- and NADP-linked glutamate dehydrogenases (EC 1.4.1.2 and 1.4.1.4) by the method of Doherty (1970).

Purification of polyamine oxidase. (a) Preparation of crude extract. Frozen $C$. boidinii grown on spermidine or 1,3diaminopropane was suspended in 2 vol. $50 \mathrm{~mm}$-potassium phosphate $\mathrm{pH} 7.0$ and passed through a French pressure cell (Haywood \& Large, 1981). The extract was centrifuged at $40000 \mathrm{~g}$ at $4{ }^{\circ} \mathrm{C}$ for $20 \mathrm{~min}$ and the pellet resuspended in 1 vol. of the same buffer and passed through the French press. After centrifuging as before the supernatants from both treatments were combined.

(b) Ammonium sulphate concentration. Solid ammonium sulphate was added slowly at $4{ }^{\circ} \mathrm{C}$ with stirring to the crude extract to $90 \%$ saturation $(3.5 \mathrm{M})$. The precipitated protein was dissolved in the smallest possible volume of $50 \mathrm{~mm}$-potassium phosphate buffer $\mathrm{pH} 7 \cdot 0$. Purification was typically $1 \cdot 3$ - to 2 -fold.

(c) Sepharose 6B chromatography. The material from step $(b)$ was applied to a column $(100 \mathrm{~cm} \times 2.5 \mathrm{~cm}$ diameter) of Sepharose $6 \mathrm{~B}$ equilibrated in $20 \mathrm{~mm}$-potassium phosphate $\mathrm{pH} 7.0$ and washed at $4{ }^{\circ} \mathrm{C}$ with the same buffer. Fractions containing more than $50 \%$ of the maximum activity were combined. Purification was typically $2-$ to 3-fold.

(d) Chromatography on 4-aminobutyl-agarose. The material was then applied to a column $(10 \mathrm{~cm} \times 2.5 \mathrm{~cm}$ diameter) of 4-aminobutyl-agarose (Sigma) and washed with the same buffer ( $20 \mathrm{~mm}$-potassium phosphate). The column was then eluted at $4{ }^{\circ} \mathrm{C}$ with a linear gradient of 0 to $1.5 \mathrm{M}-\mathrm{NaCl}$ in $20 \mathrm{~mm}$-potassium phosphate $\mathrm{pH} 7 \cdot 0$. Fractions containing more than $50 \%$ of the maximum activity were combined and bovine serum albumin added to a final concentration of $5 \mathrm{mg} \mathrm{ml}^{-1}$. Purification was typically 6- to 12 -fold.

This preparation produced overall 20 - to 100 -fold purified polyamine oxidase in a yield of about $20 \%$. The specific activity of the purified material varied from 15 to 30 units (mg protein) ${ }^{-1}$.

Enzymic changes during adaptation from growt h on ammonia to growth on spermidine. Candida boidinii was grown in 31 medium containing $15 \mathrm{mM}$-ammonium and $55 \mathrm{~mm}$-glucose. The cells were centrifuged at $13000 \mathrm{~g}$ at $30^{\circ} \mathrm{C}$ and resuspended in approximately $1000 \mathrm{ml}$ sterile carbon- and nitrogen-free medium and $500 \mathrm{ml}$ of this was added to each of two 201 fermenters, one containing $15 \mathrm{~mm}$-ammonium and $55 \mathrm{~mm}$-glucose, the second containing $55 \mathrm{~mm}$ glucose and $5 \mathrm{~mm}$-spermidine. The two cultures were thus equivalent in molarity of nitrogen. Growth was followed 
by measuring $A_{663}$. Samples were taken at approximately $4 \mathrm{~h}$ intervals, centrifuged at $13000 \mathrm{~g}$, the supernatant retained for analysis, and the cells washed in $50 \mathrm{~mm}$-potassium phosphate $\mathrm{pH} 7 \cdot 0$, and stored at $-15^{\circ} \mathrm{C}$. The samples of media were used to determine the $\mathrm{pH}$, glucose concentration and nitrogen-source concentration. Ammonia and other amines were known from preliminary experiments not to accumulate in the spermidine growth medium. Cell-free extracts were prepared as described by Haywood \& Large (1981).

Stoicheiometry of the polyamine oxidase reaction. The stoicheiometry was determined using di- $n$-butylamine as substrate. The reaction mixture contained $135 \mu \mathrm{g}$ purified enzyme, $200 \mu \mathrm{mol}$ sodium borate buffer $\mathrm{pH} 10 \cdot 0$ and water, in a final volume of $3.4 \mathrm{ml}$. The reaction was started by addition of $0.5 \mu \mathrm{mol} \mathrm{di}-n$-butylamine hydrochloride and oxygen consumption followed at $25^{\circ} \mathrm{C}$ in a Rank oxygen electrode calibrated by the method of Robinson \& Cooper (1970). When no further oxygen was consumed, $60 \mu \mathrm{g}$ beef liver catalase was added and oxygen evolution followed to a plateau. The reaction was then stopped by addition of $0.3 \mathrm{ml} 2.5 \mathrm{M}-\mathrm{HClO}_{4}$ and neutralized with $\mathrm{KOH}$. A control incubation was followed over the same period of time in which enzyme was replaced by boiled enzyme. Oxygen and $\mathrm{H}_{2} \mathrm{O}_{2}$ were determined from the oxygen electrode readings, the other components of the reaction mixture were estimated as described below. Similar experiments were done in which di- $n$-butylamine was replaced by either spermidine or spermine.

Chemical estimations. Ammonia was determined by the indophenol method (Chaney \& Marbach, 1962), and 1pyrroline with 2-aminobenzaldehyde (Bachrach \& Oser, 1963); di- $n$-butylamine was estimated by GLC at $200{ }^{\circ} \mathrm{C}$ on a column of Carbopak B coated with Carbowax $20 \mathrm{M}$ and $0.3 \% \mathrm{KOH}$ as described by Di Corcia \& Samperi (1974). Glucose was measured with a Boehringer GOD-Perid blood sugar test combination. Protein was determined by the Bradford (1976) method. Butyraldehyde was determined with yeast aldehyde dehydrogenase as described by Lundquist (1958), $n$-butylamine, spermine, spermidine and putrescine were determined enzymically as follows. The neutralized sample (2-100 nmol primary amino groups) in a volume of up to $1.5 \mathrm{ml}$ was added to a polystyrene cuvette containing $2.5 \mu \mathrm{mol}$ disodium ABTS, $200 \mu \mathrm{mol}$ potassium phosphate buffer $\mathrm{pH} 7.0$ and $100 \mu \mathrm{g}$ horseradish peroxidase in a total volume of $3 \mathrm{ml}$. The reaction was started by adding $25 \mu \mathrm{g}$ purified benzylamine/putrescine oxidase from Pichia pastoris (Green et al., 1983). The increase in absorbance at $405 \mathrm{~nm}$ was followed to completion (about $2 \mathrm{~min}$ ) and the amount of ABTS radical cation formed was calculated using an absorption coefficient of $18.41 \mathrm{mmol}^{-1} \mathrm{~cm}^{-1}$. One mol of ABTS is equivalent to $0.5 \mathrm{~mol}$ of primary amino group. This method cannot be applied to mixtures of the above amines, only to individual compounds.

Thin-layer and ion-exchange chromatography. 2,4-Dinitrophenylhydrazones of aliphatic aldehydes were separated on cellulose thin-layer plates in heptane saturated with methanol as described by Eady et al. (1971). Aliphatic amines were separated on cellulose in butan-1-ol/ $\mathrm{HCl} /$ water $(7: 2: 1$, by vol.) (Blau, 1961) and putrescine and polyamines on cellulose in propan-2-ol/HCl/water $(80: 30: 2$, by vol.) (Yamada et al., 1980a). Putrescine, spermidine and spermine were also separated by ion-exchange on a Zeo Karb 225 column, eluting with a linear gradient of $0 \cdot 5-5 \mathrm{M}-\mathrm{HCl}$, as described by Gahl \& Pitot (1982). After separation, combined fractions of each peak were identified by thin-layer chromatography in propan-2-ol/HCl/water and estimated as described above.

Molecular weight determinations. The molecular weight of polyamine oxidase was determined by molecular exclusion chromatography on Sephadex G-150 as described by Andrews (1970). The molecular weight standard proteins were cytochrome $c(12400)$, peroxidase $(40000)$, malate dehydrogenase $(70000)$, lactate dehydrogenase (130000), alcohol dehydrogenase (141000), aldolase (158000) and pyruvate kinase (235000). The molecular weight was also determined by polyacrylamide gel electrophoresis by the method of Hedrick \& Smith (1968), as described in detail by Haywood \& Large (1981). A third method used was the sucrose gradient centrifugation method of Martin \& Ames (1961), comparing the sedimentation of polyamine oxidase with that of pyruvate kinase and lactate dehydrogenase.

Preparation of spheroplasts. Freshly harvested cells of $C$. boidinii were centrifuged, washed and resuspended in solution A (3 M-sorbitol, $1 \mathrm{mM}$-EDTA, $1 \mathrm{mM}-\mathrm{MgCl}_{2}$ in $70 \mathrm{~mm}$-potassium phosphate $\mathrm{pH} 7 \cdot 0$ ) for osmotic stabilization. After $10 \mathrm{~min}$ at $0^{\circ} \mathrm{C}$ the cells were centrifuged at $10000 \mathrm{~g}$ for $10 \mathrm{~min}$ at $4{ }^{\circ} \mathrm{C}$, and the pellet resuspended in solution $\mathrm{A}\left(200 \mathrm{mg}\right.$ wet $\left.\mathrm{wt} \mathrm{ml}^{-1}\right)$. Zymolyase 5000 was added to a final concentration of $1 \mathrm{mg} \mathrm{ml}^{-1}$ (Osumi et al., 1975) and the mixture incubated at $30^{\circ} \mathrm{C}$ for $2 \mathrm{~h}$. Mercaptoethanol was omitted because it inhibits amine oxidase activity (Zwart et al., 1980). Spheroplast formation was monitored in the microscope. An equal volume of solution B (1 mM-EDTA, $1 \mathrm{~mm}-\mathrm{MgCl}_{2}$ in $70 \mathrm{~mm}$-potassium phosphate $\left.\mathrm{pH} 7 \cdot 0\right)$ was added and the mixture left for $15 \mathrm{~min}$ at $0^{\circ} \mathrm{C}$. The spheroplasts were centrifuged at $5000 \mathrm{~g}$ for $5 \mathrm{~min}$ and the pellet resuspended in solution $\mathrm{C}$ ( $1.5 \mathrm{M}$-sorbitol, $1 \mathrm{~mm}$-EDTA, $1 \mathrm{~mm}-\mathrm{MgCl}_{2}$ in $70 \mathrm{~mm}$-potassium phosphate $\mathrm{pH} 7 \cdot 0$ ).

Cell fractionation. Spheroplasts were broken in a Potter hand homogenizer (with a Teflon plunger), and the product was examined in the microscope to confirm breakage. Unbroken spheroplasts were removed by centrifuging at $5000 \mathrm{~g}$ for $5 \mathrm{~min}$. Organelles were then sedimented at $30000 \mathrm{~g}$ for $15 \mathrm{~min}$ and resuspended in solution $C$. Any unsuspended material was removed by centrifuging at $5000 \mathrm{~g}$ for a further $5 \mathrm{~min}$.

The material so obtained was layered $(2 \mathrm{ml})$ on to a discontinuous sucrose gradient prepared in a $15 \mathrm{ml}$ Sorvall centrifuge tube. The gradient was made by pipetting successive samples of $75 \%(1 \mathrm{ml}), 60 \%(1 \mathrm{ml}), 45 \%(1 \mathrm{ml})$, $40 \%(2 \mathrm{ml}), 35 \%(2 \mathrm{ml}), 30 \%(2 \mathrm{ml})$ and $25 \%(1 \mathrm{ml})$ sucrose $(\mathrm{w} / \mathrm{v})$ in $0 \cdot 2 \mathrm{M}$-potassium phosphate $\mathrm{pH} 7 \cdot 0$. The 
gradient was then centrifuged at $50000 \mathrm{~g}$ for $60 \mathrm{~min}$ in a Sorvall SS34 angle head at $4{ }^{\circ} \mathrm{C}$ and $1 \mathrm{ml} \mathrm{fractions} \mathrm{were}$ removed successively from the top of the tube and assayed for the activity of polyamine oxidase, cytochrome $c$ oxidase, NADH dehydrogenase, catalase and NAD-linked glycerol-3-phosphate dehydrogenase. The sucrose concentration was determined by measuring the refractive index of the individual fractions.

\section{RESULTS}

Candida boidinii grew poorly and unpredictably with a long lag period on a defined medium with $5 \mathrm{~mm}$-spermine tetrahydrochloride as sole nitrogen source and glucose as carbon source, but grew well when spermine was replaced by $5 \mathrm{~mm}$-spermidine trihydrochloride. This is similar to the observations of Yamada et al. $(1980 a)$ with Aspergillus terreus. The precipitate from a $95 \%$ saturation ammonium sulphate treatment of crude extracts of cells grown on spermidine when tested by spectrophotometric assay at $\mathrm{pH} 7 \cdot 0$ showed low activity with the following amines [rates are nmol ABTS radical cation formed $\min ^{-1}$ (mg protein) ${ }^{-1}$ ]: spermidine 0.43 and spermine 4.7 when tested at $3.3 \mathrm{~mm} ; 0.33 \mathrm{~mm}$-benzylamine and $n$-butylamine were also active [23 and 76 munits (mg protein) ${ }^{-1}$, respectively]. Lower concentrations of polyamines showed no activity at $\mathrm{pH} 7 \cdot 0$. When the $\mathrm{pH}$ optimum for polyamine oxidation was examined, spermidine and spermine both showed a $\mathrm{pH}$ optimum in the region of 10.0 . At this $\mathrm{pH}$ value activity was not very stable, and so the more rapid spectrophotometric assay was usually preferred. No activity could be detected in the region of $\mathrm{pH} 5.0$ with $C$. boidinii extracts, in contrast to the results with spermine and spermidine oxidation in Penicillium species (Isobe et al., $1980 a$; Kobayashi \& Horikoshi, 1982).

The Penicillium polyamine oxidases were also stable at acid $\mathrm{pH}$ values (Isobe et al., $1980 \mathrm{a}$; Kobayashi \& Horikoshi, 1982), but when crude extracts of spermidine-grown C. boidinii were held at various $\mathrm{pH}$ values in the range 3.8 to 11.2 at $0{ }^{\circ} \mathrm{C}$ for $64 \mathrm{~h}, 8.6 \%$ of the initial activity survived at $\mathrm{pH} 7.0$ and $3.1 \%$ of the activity at $\mathrm{pH} 8.0$, but no activity survived at other $\mathrm{pH}$ values. Essentially similar observations were made in experiments involving shorter incubation periods. Thus the enzyme was unstable even at neutral $\mathrm{pH}$ values.

\section{Role of polyamine oxidase in growth on spermidine}

The time course of the synthesis of various enzymes was examined during the adaptation of $C$. boidinii grown on ammonium as nitrogen source to growth on spermidine as nitrogen source (Fig. 1). The cells were compared with a control culture growing on ammonium (Fig. 2). No polyamine oxidase was detectable at any stage during growth on ammonium (Fig. $2 a$ ) but transfer to spermidine produced an immediate, rapid synthesis of the enzyme together with an increase in the specific activity of catalase (Fig. $1 b$ ) before growth on spermidine began. Activities of polyamine oxidase and catalase remained high well into the stationary phase of growth. (Both the spermidine and ammonium cultures become carbon-limited quite rapidly.) Benzylamine oxidase also increased in specific activity during exponential growth, but fell thereafter (Fig. 1b), while methylamine oxidase only became detectable towards the end of growth and remained at significant levels in the stationary phase. Growth on spermidine did not significantly affect the activities of isocitrate dehydrogenase or NADP-linked glutamate dehydrogenase, but produced significant elevation of NAD-linked glutamate dehydrogenase before growth began, and which remained at a high level (Fig. 1a). The control culture growing on ammonium as nitrogen source produced increased activity of NADP-linked glutamate dehydrogenase, and a small increase in catalase activity (Fig. 2a), but no benzylamine or methylamine oxidase activity was detected.

\section{Attempted stabilization of polyamine oxidase}

Possible stabilizing agents for the enzyme were tested on a partially purified preparation, namely spermine, ethanol and bovine serum albumin. Of these, only the last seemed to have a significant stabilizing effect, and this was of little use during purification. Thus it was necessary to perform the purification as quickly as possible. 


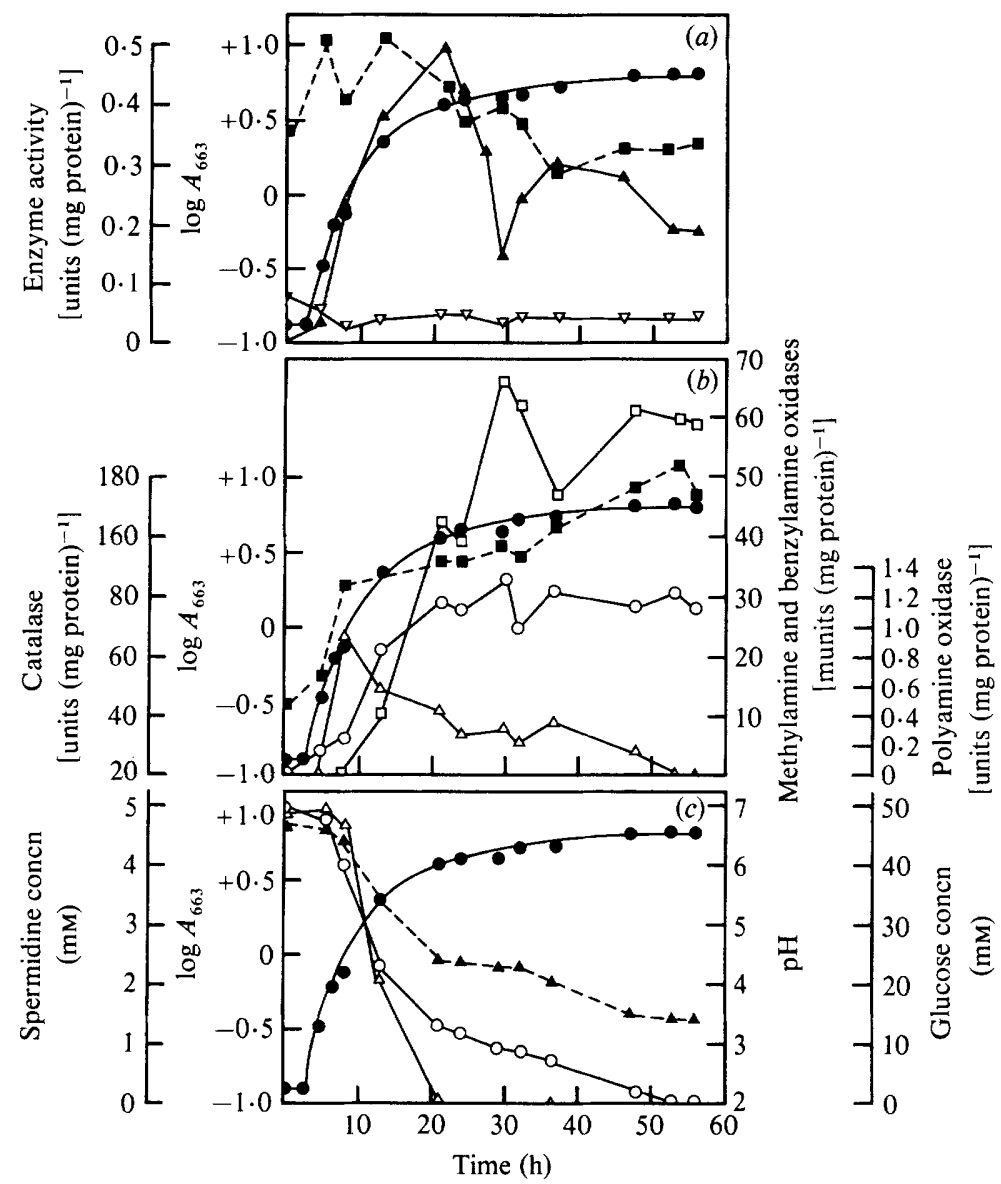

Fig. 1. Effect on growth and enzyme activity of transfer of Candida boidinii grown on ammonium as nitrogen source to medium containing spermidine as sole nitrogen source. (a) , Growth; $\nabla$, isocitrate dehydrogenase; $\boldsymbol{\Delta}$, NAD-linked glutamate dehydrogenase; $\mathbf{0}$, NADP-linked glutamate dehydrogenase (broken line). (b) $\bigcirc$, Growth; $\bigcirc$, polyamine oxidase; $\Delta$, benzylamine oxidase; $\square$, methylamine oxidase; $\boldsymbol{\square}$, catalase (broken line). (c) $\boldsymbol{O}$, Growth; $\boldsymbol{\Lambda}$, pH of culture medium (broken line); $\triangle$, glucose concentration in the medium; $O$, spermidine concentration.

\section{Partial purification of the enzyme}

Consistent yields of enzyme were obtained using the procedure described in Methods. Further purification was attempted but because of instability no improvement in specific activity was achieved. Activity of the partially purified material could only be retained by addition of $5 \mathrm{mg}$ bovine serum albumin per $\mathrm{ml}$ of enzyme preparation as a stabilizing agent, but under these conditions it was stable at $4{ }^{\circ} \mathrm{C}$ for 1 to 2 months. A sample of enzyme of specific activity $15 \cdot 1$ units (mg protein) $)^{-1}$ was examined by polyacrylamide gel electrophoresis as described by Davis (1964). Activity was detected using diaminobenzidine as described by Haywood \& Large (1981). The enzyme was about $50 \%$ pure; some seven protein impurities were detected, of which two were present in significant amounts.

\section{Properties of the partially purified enzyme}

Substrate specificity. The substrate specificity of the enzyme was examined at $\mathrm{pH} 10 \cdot 0$ (borate buffer) by the polarographic assay. The structural requirements for activity seem to be that the substrate must contain a secondary amino group and one alkyl chain longer than $\mathrm{C}_{4}$. The following were oxidized: spermine, spermidine, $N^{1}$-acetylspermidine, $N$ - $n$-butylpropylamine, 

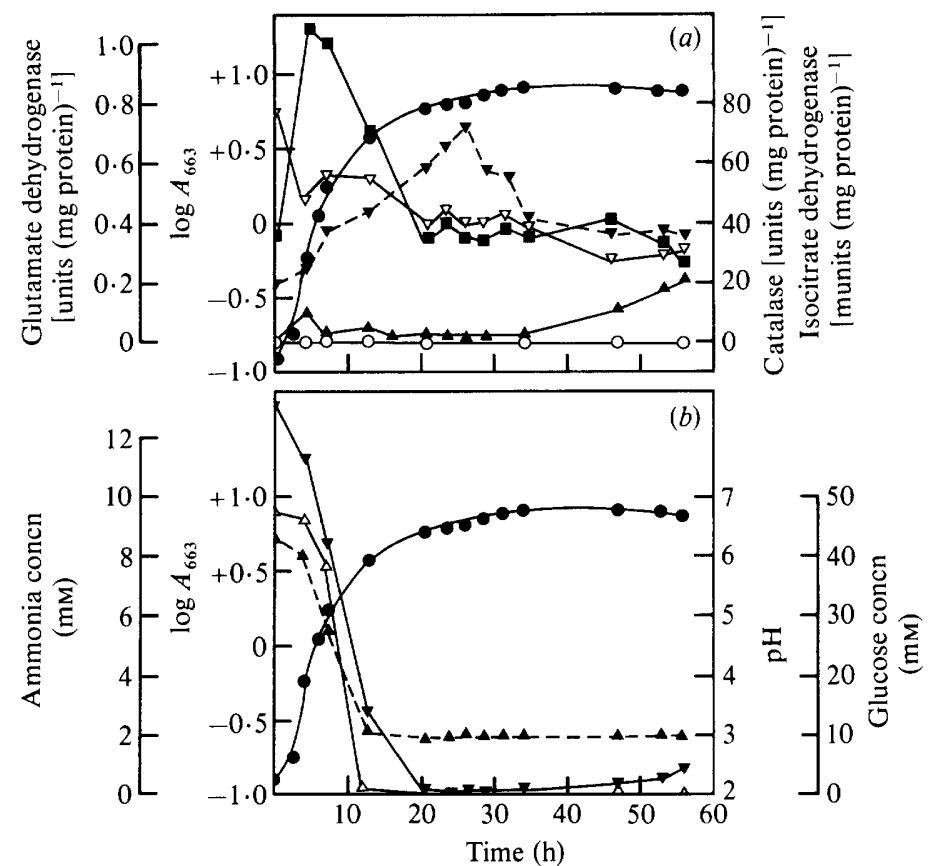

Fig. 2. Effect on growth and enzyme activity of transfer of Candida boidinii grown on ammonium as nitrogen source to fresh medium of identical composition. (a) $\odot$, Growth; $\bigcirc$, polyamine oxidase; $\nabla$, isocitrate dehydrogenase; $\boldsymbol{\Delta}$, NAD-linked glutamate dehydrogenase; $\boldsymbol{\square}$, NADP-linked glutamate dehydrogenase; $\boldsymbol{\nabla}$, catalase (broken line). (b) $\boldsymbol{\ominus}$, Growth, $\boldsymbol{\Lambda}, \mathrm{pH}$ of culture medium (broken line); $\triangle$, glucose concentration; $\boldsymbol{\nabla}$, ammonium concentration.

Table 1. Apparent $K_{\mathrm{m}}$ and $V_{\max }$ values for substrates of Candida boidinii polyamine oxidase

\begin{abstract}
Values were obtained from double-reciprocal plots of rate and substrate concentration. The best line was drawn using a linear regression program as described by Brook \& Large (1976). Values are based on a single series of experiments using one enzyme preparation for all the data in the polarographic assay and a later preparation for the data in the spectrophotometric assay. The values are thus representative and are chiefly useful for comparison between different substrates.
\end{abstract}

\section{Substrate}

Spermine

Spermidine

$N^{1}$-Acetylspermidine

$N$-n-Butylpropylamine

Di- $n$-butylamine

Di- $n$-hexylamine

\begin{tabular}{|c|c|}
\hline \multicolumn{2}{|c|}{ Polarographic assay } \\
\hline$\frac{V_{\max }}{\left.\text { [units (mg protein })^{-1}\right]}$ & $\begin{array}{l}K_{\mathrm{m}}^{\mathrm{app}} \\
(\mathrm{mM})\end{array}$ \\
\hline $8 \cdot 30$ & $0 \cdot 20$ \\
\hline 0.92 & $0 \cdot 28$ \\
\hline $23 \cdot 40$ & 0.054 \\
\hline 0.50 & 6.89 \\
\hline 0.72 & $0 \cdot 31$ \\
\hline $0 \cdot 10$ & 0.05 \\
\hline
\end{tabular}

-, Not determined.

\begin{tabular}{|c|c|}
\hline$\frac{V_{\max }}{\left.[\text { units (mg protein })^{-1}\right]}$ & $\begin{array}{r}K_{\mathrm{m}}^{\mathrm{app}} \\
(\mathrm{mM})\end{array}$ \\
\hline $8 \cdot 57$ & 0.13 \\
\hline $1 \cdot 17$ & 0.17 \\
\hline $34 \cdot 0$ & 0.03 \\
\hline- & - \\
\hline $1 \cdot 18$ & 0.57 \\
\hline
\end{tabular}

di- $n$-butylamine and di- $n$-hexylamine. The following amines were not substrates: diethylamine, di- $n$-propylamine, 3,3'-iminobispropylamine (1,7-diamino-4-azaheptane, sym-norspermidine), diethylenetriamine (1,5-diamino-3-aza-pentane), putreanine (8-amino-4-azaoctanoate), $N^{1}, N^{8}$ diacetylspermidine, methylamine, $n$-butylamine, benzylamine, agmatine, 1,2-diaminoethane, 1,3-diaminopropane, 1,4-diaminobutane (putrescine), 1,5-diaminopentane (cadaverine), 1,6diaminohexane, 1,8-diaminooctane and 2-phenylethylamine. Unlike the rat liver enzyme (Hölttä, 1977), there was no stimulation of activity by 5 mM-benzaldehyde.

Kinetic properties. Apparent $K_{\mathrm{m}}$ values and $V_{\max }$ values for active secondary amine substrates (oxygen concentration $0.25 \mathrm{mM}$ ) were determined by both assay methods (Table 1), which agreed reasonably well. 
Table 2. Inhibitors of polyamine oxidase

\begin{tabular}{|c|c|c|c|c|c|}
\hline Inhibitor & $\begin{array}{l}\text { Concn } \\
\text { tested }\end{array}$ & $\begin{array}{l}\text { Percentage } \\
\text { inhibition* }\end{array}$ & Inhibitor & $\begin{array}{l}\text { Concn } \\
\text { tested }\end{array}$ & $\begin{array}{l}\text { Percentage } \\
\text { inhibition* }\end{array}$ \\
\hline Carbonyl reagents & \multicolumn{5}{|c|}{ Substrate analogues } \\
\hline \multirow[t]{2}{*}{ Semicarbazide-HCl } & $167 \mu \mathrm{M}$ & 0 & \multirow[t]{2}{*}{ Diethylamine } & $167 \mu \mathrm{M}$ & 3 \\
\hline & $3.3 \mathrm{~mm}$ & 40 & & $3.3 \mathrm{~mm}$ & 96 \\
\hline $\mathrm{Hydroxylamine}-\mathrm{HCl}$ & $3.3 \mathrm{mM}$ & 36 & Triethylamine & $3.3 \mathrm{~mm}$ & 6 \\
\hline Iproniazid & $3.3 \mathrm{mM}$ & 47 & Tri-n-propylamine & $3 \cdot 3 \mathrm{~mm}$ & 15 \\
\hline Hydrazine- $\mathrm{HCl}$ & $3.3 \mathrm{mM}$ & 14 & 3-Dimethylaminopropylamine & $3.3 \mathrm{~mm}$ & 8 \\
\hline Chelating agents & & & Lilly $53325 \dagger$ & $0.33 \mathrm{~mm}$ & 26 \\
\hline \multirow[t]{2}{*}{ 2,2'-Bipyridyl } & \multirow{3}{*}{$\begin{array}{l}33 \mu \mathrm{M} \\
3 \cdot 3 \mathrm{mM}\end{array}$} & 67 & Lilly $18947 \ddagger$ & $0.33 \mathrm{~mm}$ & 21 \\
\hline & & 100 & \multirow{3}{*}{$\begin{array}{l}\text { Miscellaneous } \\
\text { Quinacrine-HCl }\end{array}$} & & \\
\hline Amino oxidase inhibitors & & & & $1.33 \mu \mathrm{M}$ & 2 \\
\hline trans-2-Phenyl- & $33 \mu \mathrm{M}$ & 54 & & $66 \mu \mathrm{M}$ & 97 \\
\hline cyclopropylamine & $3.3 \mathrm{mM}$ & 100 & Sodium mersalyl & $8 \cdot 3 \mu \mathrm{M}$ & 100 \\
\hline Harmaline-HCl & $0.66 \mathrm{~mm}$ & 80 & & & \\
\hline Pargyline- $\mathrm{HCl}$ & $3.3 \mathrm{mM}$ & 78 & & & \\
\hline
\end{tabular}

Effect of various possible inhibitors. Inhibitors were tested in the polarographic assay after $5 \mathrm{~min}$ preincubation with enzyme in the absence of substrate $(3.3 \mathrm{~mm}$-spermine). Those compounds that did inhibit the enzyme are listed in Table 2 . The following compounds showed no inhibition: isoniazid ( $3.3 \mathrm{~mm})$, putrescine $(3.3 \mathrm{mM})$ and phenylhydrazine $(1.3 \mathrm{mM})$. The following compounds stimulated oxygen uptake rather than inhibited it (although they showed no oxygen uptake alone): cuprizone $(84 \mu \mathrm{M})$, FAD $(17 \mu \mathrm{M})$, bromoethylamine $(0.13$ and $1.33 \mathrm{~mm})$, aminoacetonitrile $(0.33$ and $3.33 \mathrm{~mm})$, aminoguanidine $(3.3 \mathrm{~mm}), \mathrm{KCN}(3.3 \mathrm{~mm}), n$ butylamine $(3.3 \mathrm{~mm})$, EDTA $(3.3 \mathrm{~mm})$, di- $n$-propylamine, $3,3^{\prime}$-iminobispropylamine and diethylenetriamine. The stimulation by chelating agents suggested that the enzyme might be inhibited by metal ions, and $0 \cdot 1 \mathrm{mM}-\mathrm{MgCl}_{2}, \mathrm{NiCl}_{2}, \mathrm{ZnSO}_{4}$ and $\mathrm{CuCl}_{2}$ were all shown to be potent inhibitors. Addition of EDTA at $3.3 \mathrm{~mm}$ partially relieved this inhibition.

Attempted resolution of the enzyme. By analogy with polyamine oxidase of moulds and mammals, it seemed likely that the enzyme should contain FAD. However, attempts to resolve the enzyme by treatment with $1.5 \mathrm{M}-\mathrm{KBr}$ followed by acidified saturated ammonium sulphate as described by Hölttä (1977) produced an inactive precipitate which showed no reactivation even after incubation for $2 \mathrm{~h}$ at $0{ }^{\circ} \mathrm{C}$ in the presence of $33 \mu \mathrm{M}$-riboflavin, FMN or FAD. This loss of activity is probably due to the much greater instability of the yeast enzyme. No direct spectral measurements on the purified enzyme were possible because it was too dilute and lost activity on pressure concentration.

Identity of reaction products and stoicheiometry. The fact that longer chain secondary amines are substrates suggests that the enzyme oxidizes only secondary amino groups. When di- $n$ butylamine was incubated with enzyme for $24 \mathrm{~h}$, the reaction products contained no ammonia. Half of the reaction mixture was made alkaline and extracted with butan-1-ol. The butanol layer contained a ninhydrin-positive material which on TLC on cellulose in butan-1-ol/ $\mathrm{HCl} /$ water had an $R_{F}$ of $0.81\left(R_{F}\right.$ values of primary amine markers were $0.54,0.69,0.81$ and 0.86 for ethylamine, $n$-propylamine, $n$-butylamine and $n$-amylamine, respectively). The other half of the reaction mixture was treated with $1 \mathrm{~mm}$-2,4-dinitrophenylhydrazine in $2 \mathrm{M}-\mathrm{HCl}$. After $10 \mathrm{~min}$ it was extracted with chloroform and on TLC on cellulose in heptane saturated with methanol, a 2,4-dinitrophenylhydrazone was identified with an $R_{F}$ of $0.83\left(R_{F}\right.$ values of dinitrophenylhydrazones of standards were: acetaldehyde 0.58 , propionaldehyde 0.74 , butyraldehyde 0.82 ). In order to establish the stoicheiometry for the cleavage of di- $n$-butylamine into monobutylamine and butyraldehyde, the enzyme was incubated with substrate in the oxygen electrode as described in Methods. The oxidation of $305 \mathrm{nmol}$ of di- $n$-butylamine was accompanied by an 
oxygen consumption of $315 \mathrm{nmol}$ and $315 \mathrm{nmol} \mathrm{H}_{2} \mathrm{O}_{2}, 283 \mathrm{nmol} n$-butylamine and $279 \mathrm{nmol}$ butyraldehyde were formed in accordance with the following equation:

$$
\left(\mathrm{CH}_{3}\left[\mathrm{CH}_{2}\right]_{3}\right)_{2} \mathrm{NH}+\mathrm{O}_{2}+\mathrm{H}_{2} \mathrm{O} \rightarrow \mathrm{CH}_{3}\left[\mathrm{CH}_{2}\right]_{3} \mathrm{NH}_{2}+\mathrm{CH}_{3}\left[\mathrm{CH}_{2}\right]_{2} \mathrm{CHO}+\mathrm{H}_{2} \mathrm{O}_{2}
$$

In the case of spermidine it seemed likely that here also the reaction would involve oxidation of the secondary amino group. Determination of ammonia formed with spermidine as substrate showed the formation of $0.26 \mathrm{~mol} \mathrm{NH}$ per mol oxygen consumed, and for spermine the ratio was 0.043 , compared with a ratio of $1.19 \mathrm{~mol} \mathrm{NH}_{3}$ per $\mathrm{mol} \mathrm{O}_{2}$ for spermidine oxidation by the benzylamine/putrescine oxidase of Pichia pastoris (Green et al., 1983). The question also arose as to whether the cleavage was between the $\mathrm{C}_{3}$ carbon chain of spermidine and the secondary nitrogen atom (giving 1,4-diaminobutane and 3-aminopropionaldehyde) or between the $\mathrm{C}_{4}$ chain and the secondary nitrogen atom (giving 1,3-diaminopropane and 4-aminobutyraldehyde, which spontaneously cyclizes to 1-pyrroline). Incubation of the reaction products with 2aminobenzaldehyde failed to give a yellow colour (due to 1-pyrroline; Bachrach \& Oser, 1963), so that it seemed likely that the cleavage was between the $\mathrm{C}_{3}$ chain and the secondary nitrogen atom. This was confirmed by an experiment in which the reaction products of spermine and spermidine oxidation were separated on a Zeo-Karb 225 ion-exchange column. The oxidation of $433 \mathrm{nmol}$ spermidine was accompanied by an oxygen consumption of $320 \mathrm{nmol}$ and of the products formed there were $320 \mathrm{nmol} \mathrm{H}_{2} \mathrm{O}_{2}$ and $330 \mathrm{nmol}$ putrescine. In the case of spermine the oxidation of $325 \mathrm{nmol}$ by $450 \mathrm{nmol}$ of oxygen gave $75 \mathrm{nmol}$ spermidine and $234 \mathrm{nmol}$ putrescine.

The unknown $\mathrm{C}_{3}$ derivative which was also formed gave a thiosemicarbazone with $\lambda_{\max }$ $262 \mathrm{~nm}$ and a 2,4-dinitrophenylhydrazone with $\lambda_{\max } 372 \mathrm{~nm}$. The latter was insoluble in chloroform. On TLC of the aqueous layer on silica gel G in butan-1-ol/ammonia ( $70: 30$, by vol.) or ethanol/ammonia ( $70: 30$, by vol.) a spot was identified, $R_{F} 0.24$ in the first solvent and 0.33 in the second, which had the same $R_{F}$ values as the 2,4-dinitrophenylhydrazone of the oxidation product of 3-aminopropanol by liver alcohol dehydrogenase, which, according to Hölttä (1977), is 3-aminopropionaldehyde. The product certainly cannot be acrolein (Kimes \& Morris, 1971; Gahl \& Pitot, 1982), whose 2,4-dinitrophenylhydrazone is soluble in chloroform.

Molecular weight of the polyamine oxidase. Considerable variation in the molecular weight value was found, depending on the method by which it was determined. By using Sephadex G150 with molecular weight markers in the range 12400 to 235000 (see Methods), a value of 79500 was obtained for the partially purified enzyme and 90000 for crude enzyme. With the method of Hedrick \& Smith (1968), in which the retardation coefficient (Ferguson, 1964) determined by non-denaturing polyacrylamide gel electrophoresis is compared with those of standard proteins, crude cell extracts gave a molecular weight value of 200000 . In this experiment the enzyme was detected by activity staining (see Green et al., 1982). Using the sucrose density gradient method of Martin \& Ames (1961) with appropriate standard proteins, a value of 111000 for the molecular weight was obtained.

\section{Distribution of the enzyme in $C$. boidinii grown on different nitrogen sources}

The enzyme was found to be present in lower but significant levels in cells grown on a number of other nitrogen sources (Table 3) besides spermidine, namely 1,3-diaminopropane, putrescine and cadaverine.

\section{Metabolism of putrescine by $C$. boidinii}

Cells of $C$. boidinii grew well on putrescine, but although they contained polyamine oxidase activity, which presumably is gratuitously induced (Table 3 ), no putrescine oxidase activity was detected. However crude extracts did give a positive result when tested for the activity of diamine aminotransferase (EC 2.6.1.29) by the method of Kim (1964) (Table 3).

The product of either oxidation or transamination of putrescine is 4-aminobutyraldehyde (1pyrroline) and it has been established that 1-pyrroline can be oxidized by crude extracts of a number of yeasts (Table 4), as well as by purified benzylamine oxidase from $C$. boidinii. 
Table 3. Distribution of enzymes of polyamine and nitrogen metabolism in Candida boidinii, C. utilis and Pichia pastoris

\begin{tabular}{|c|c|c|c|c|c|c|c|c|}
\hline \multirow[b]{2}{*}{ Growth substrate } & \multicolumn{8}{|c|}{ Specific activity $\left[\mathrm{nmol} \min ^{-1}(\mathrm{mg} \text { protein })^{-1} ;\right.$ except catalase, $\mu \mathrm{mol} \min ^{-1}(\mathrm{mg} \text { protein })^{-1}$} \\
\hline & $\begin{array}{l}\text { Methylamine } \\
\text { oxidase }\end{array}$ & $\begin{array}{l}\text { Benzylamine } \\
\text { oxidase }\end{array}$ & $\begin{array}{c}\text { Polyamine } \\
\text { oxidase }\end{array}$ & $\begin{array}{l}\text { Putrescine } \\
\text { oxidase }\end{array}$ & $\begin{array}{l}\text { Putrescine } \\
\text { amino- } \\
\text { transferase }\end{array}$ & $\frac{\begin{array}{r}\text { Glut } \\
\text { dehydr }\end{array}}{\text { NAD }}$ & $\underbrace{\text { ogenate }}_{\text {NADP }}$ & Catalase \\
\hline & \multicolumn{8}{|c|}{ Candida boidinii } \\
\hline Ammonium & 0 & 0 & 0 & 0 & 0.7 & 0 & 350 & 19 \\
\hline Methylamine & 81 & 3 & 0 & 0 & 4.9 & 16 & 670 & 133 \\
\hline Dimethylamine & 196 & 0 & 0 & 0 & $6 \cdot 9$ & 10 & 490 & 216 \\
\hline$n$-Butylamine & 39 & 20 & 0 & 0 & $4 \cdot 8$ & 0 & 630 & 180 \\
\hline Choline & 54 & 0 & 0 & 0 & $4 \cdot 8$ & 23 & 290 & 151 \\
\hline Lysine & 0 & 0 & 0 & 0 & $0 \cdot 3$ & 133 & 290 & 25 \\
\hline 1,3-Diaminopropane & 1 & 24 & 110 & 0 & $3 \cdot 9$ & 83 & 590 & 146 \\
\hline Putrescine & 0 & 16 & 47 & 0 & $2 \cdot 1$ & 121 & 146 & 62 \\
\hline Cadaverine & 5 & 30 & 7 & 0 & 1.4 & 204 & 530 & 177 \\
\hline 1,6-Diaminohexane & 0 & 1 & 0 & 0 & 0 & 20 & 1490 & 155 \\
\hline \multirow[t]{2}{*}{ Spermidine } & 0 & 5 & 514 & 0 & $2 \cdot 2$ & 178 & 138 & 67 \\
\hline & \multicolumn{8}{|c|}{ Candida utilis } \\
\hline Ammonium & 0 & 0 & 0 & 0 & 0 & 4 & 27 & 45 \\
\hline$n$-Butylamine & 36 & 118 & 0 & 11 & $8 \cdot 8$ & 64 & 291 & 171 \\
\hline 1,3-Diaminopropane & 4 & 182 & 0 & 25 & 5.9 & 4 & 18 & 132 \\
\hline \multirow[t]{2}{*}{ Putrescine } & 0 & 141 & 0 & 10 & $1 \cdot 8$ & 2 & 22 & 143 \\
\hline & \multicolumn{8}{|c|}{ Pichia pastoris } \\
\hline Ammonium & 0 & 0 & 0 & 0 & $2 \cdot 5$ & 10 & 21 & 21 \\
\hline Putrescine & 6 & 5 & 0 & 16 & $2 \cdot 3$ & 206 & 156 & 101 \\
\hline Spermidine & 37 & 7 & 0 & 47 & 0.7 & 87 & 143 & 104 \\
\hline
\end{tabular}

\section{Peroxisomal location of polyamine oxidase}

A cell-fractionation technique based on that of Zwart (1983) was used to determine the intracellular location of polyamine oxidase activity. The mitochondria/peroxisome fraction, isolated from mechanically broken spheroplasts (see Methods) by centrifugation at $30000 \mathrm{~g}$ for $15 \mathrm{~min}$ was centrifuged on a discontinuous sucrose gradient as described in Methods, to separate mitochondria and peroxisomes. Due to the size of the organelles in C. boidinii, good separations between the two fractions were not easily obtained, but it is clear from Fig. 3(c) that polyamine oxidase co-sediments with catalase and glycerol-3-phosphate dehydrogenase, both of which are known to be peroxisomal enzymes in yeast (Yamada et al., 1980b; Zwart et al., 1980; Kawamoto et al., 1979). The mitochondrial marker enzymes cytochrome oxidase (Delaissé et al., 1981; Zwart, 1983) and NADH dehydrogenase (Von Jagow \& Klingenberg, 1970) end up at a slightly lower sucrose concentration (Fig. $3 b$ ). Some catalase activity was also found in this fraction (Fig. $3 c$ ). Poor separation between peroxisomes and mitochondria was also observed in $C$. stellatoidea by Jenkins et al. (1983).

Presence of polyamine oxidase in other yeast species

Polyamine oxidase activity at $\mathrm{pH} 10 \cdot 0$ was found in the following yeast species when grown on spermidine as sole nitrogen source: $C$. boidinii, $C$. nagoyaensis, Hansenula polymorpha and Trichosporon melibiosaceum (Table 4). Other organisms which contained polyamine oxidase activity when tested at $\mathrm{pH} 7 \cdot 0$, but not at $\mathrm{pH} 10 \cdot 0$ were: $C$. steatolytica, Pichia pastoris and Sporopachydermia cereana. These organisms also contained putrescine oxidase activity (Table 4 ), and it seems likely that both activities are due to a benzylamine/putrescine oxidase similar to that already characterized in $P$. pastoris (Green et al., 1983). 


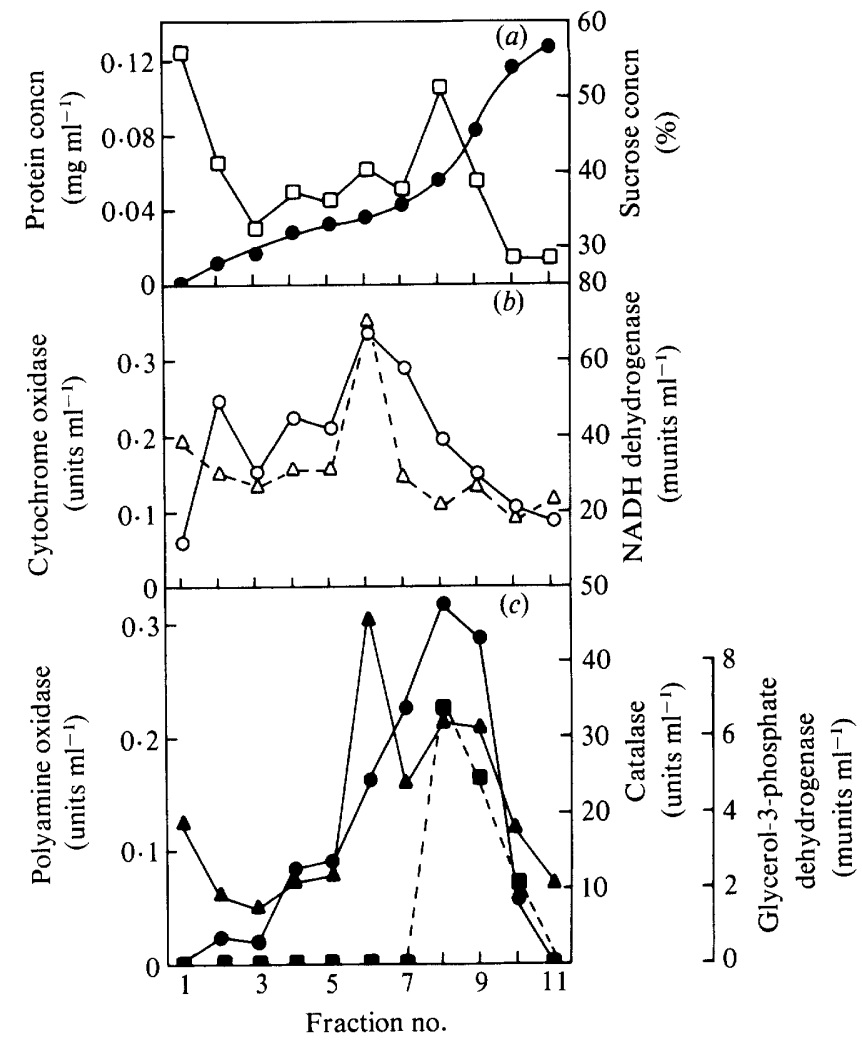

Fig. 3. Separation of mitochondrial and peroxisomal enzyme activities of Candida boidinii by sucrosegradient centrifugation. (a) $\bullet$, Sucrose concentration; $\square$, protein concentration. (b) $\bigcirc$, Cytochrome oxidase; $\triangle$, NADH dehydrogenase. $(c) \bullet$, Polyamine oxidase; $\Delta$, catalase; $\square$, NAD-linked glycerol3-phosphate dehydrogenase (broken line).

Table 4. Distribution of enzymes of polyamine and nitrogen metabolism in various yeast species grown on spermidine

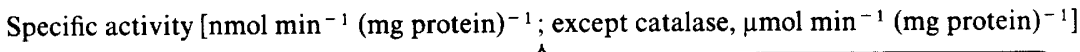

\section{Yeast}

Candida boidinii

C. insectalens

C. nagoyaensis

C. steatolytica

Hansenula minuta

H. polymorpha

Pichia pastoris

P. pinus

Sporopachydermia

cereana

Trichosporon

melibiosaceum
Spermine

Methyl- Benzyl- 1- oxidase

amine amine Pyrroline ${ }^{\text {Putrescine }}$ oxidase oxidase oxidase $\mathrm{pH} 7.0 \mathrm{pH} 10.0$ oxidase

$\begin{array}{rrrrr}0 & 5 & 20 & 0 & 514 \\ 0 & 14 & 34 & 0 & 1 \\ 19 & 91 & 2 & 0 & 10 \\ 0 & 21 & 0 & 16 & 0 \\ 0 & 8 & 1 & 0 & 0 \\ 34 & 28 & 1 & 0 & 12 \\ 37 & 7 & - & 17 & 0 \\ 17 & 39 & 1 & 1 & 2\end{array}$

Glutamate

Putrescine dehydrogenase

amino-

transferase NAD NADP Catalase

$\begin{array}{rrrr}3 & 178 & 138 & 67 \\ - & 14 & 47 & 378\end{array}$

$1-0$

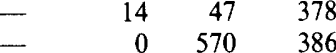

$\begin{array}{rrr}-\quad 28 \quad 174 \\ -\quad 9 & 170\end{array}$

$\begin{array}{lll}- & 9 & 170\end{array}$

$\begin{array}{rrrr}- & 0 & 340 & 60\end{array}$

$\begin{array}{llll}1 & 87 & 143 & 104\end{array}$

1739

$\begin{array}{lllll}48 & 10 & 11 & 15 & 0\end{array}$

1
$-\quad 98 \quad 326$

246

$\begin{array}{lllll}0 & 0 & 1 & 0 & 90\end{array}$

39

$\begin{array}{llll}- & 0 & 0 & 285\end{array}$

-, No data available. 
DISCUSSION

The role of polyamine oxidase in the dissimilation of spermidine is clearly demonstrated by its induction before growth on spermidine begins (Fig. 1). The properties of the enzyme (e.g. pH optimum, products formed) resemble those of liver polyamine oxidase (Hölttä, 1977). It seems likely that despite the difference of stability, yeast polyamine oxidase is, like the liver and mould enzymes (Isobe et al., 1980a; Kobayashi \& Horikoshi, 1982), a flavoprotein. We have shown that polyamine oxidase is peroxisomal, like the liver enzyme. Growth on spermidine is also accompanied by elevated activities of catalase (Fig. 1 and Table 3), which is also a peroxisomal enzyme (Tolbert, 1981) and necessary for the removal of $\mathrm{H}_{2} \mathrm{O}_{2}$ formed by polyamine oxidase. Yeast polyamine oxidase differs from that found in liver by the fact that it is not stimulated by aldehydes (Hölttä, 1977). Several workers have recently described polyamine oxidases from fungi, both intracellular (Yamada et al., 1980a; Isobe et al., 1980a,b,c) and extracellular (Kobayashi \& Horikoshi, 1981, 1982), but the yeast enzyme differs from that found in moulds by being significantly less stable and in failing to show activity in the $\mathrm{pH}$ region from 4 to 6 (Isobe et al., 1980a; Kobayashi \& Horikoshi, 1982). The apparently narrow substrate specificity observed with the mould enzymes is probably due to failure of the experimenters to test long chain secondary amines, which we found to be fairly good substrates. Yeast polyamine oxidase also differs from putrescine oxidase from Micrococcus rubens (EC 1.4.3.10) (Yamada et al., 1965; Swain \& DeSa, 1976; Okada et al., 1979) in its total failure to oxidize putrescine or cadaverine. No polyamine oxidase seems to have been tested for activity with dialkylamines in the way in which Okada et al. (1979) tested putrescine oxidase. This is undoubtedly due to the fact that most of the analogues studied by Okada et al. (1979) had to be synthesized. However, using only commercially available secondary amines we have been able to show that unlike putrescine oxidase (for which the essential structural feature for a substrate to show activity is $\mathrm{NH}_{2}\left(\mathrm{CH}_{2}\right)_{4} \mathrm{NH}-$ ), our enzyme is active with dialkylamines of structure $\mathrm{RNHR}^{1}$ where $\mathrm{R}$ must be at least $C_{4}$ and $R^{1}$ at least $C_{3}$. The presence of a primary amino group is not essential for activity. This is also borne out by the other active substrates (Table 1), whose range resembles that of the rat liver enzyme (Hölttä, 1977; Bolkenius \& Seiler, 1981; Suzuki et al., 1981) rather than the mould enzyme (Kobayashi et al., 1983). $N^{1}$-Acetylspermidine seems to be the best substrate for the enzyme, and one wonders whether acetylation might precede spermidine oxidation, as probably occurs in mammals (Seiler et al., 1980; Bolkenius \& Seiler, 1981; Matsui et al., 1983). In the case of the extracellular Penicillium enzyme (Kobayashi et al., 1983), $N^{1}$ acetylspermidine was a much poorer substrate than spermidine, and this was true for acetylated polyamines in general.

Smith (1972) has classified the various ways in which enzymic attack on polyamines can occur. We have shown that benzylamine/putrescine oxidase of Pichia pastoris attacks the two primary amino groups of both spermine and spermidine (Green et al., 1983). Spermine is thus oxidized by $P$. pastoris in the same way (mechanism 6 of Smith, 1972) as by plasma amine oxidase (Tabor et al., 1964). Spermidine was oxidized by $P$. pastoris at both primary amino groups, a new mechanism. With the present polyamine oxidase however, the secondary amino group(s) of spermidine and spermine are cleaved to yield putrescine and one or two molecules of what is probably 3-aminopropionaldehyde, which are mechanisms 1 and 2 of Smith (1972), in the same way as the enzymes from liver (Hölttä, 1977) and Penicillium (Yamada et al., 1980a; Kobayashi \& Horikoshi, 1982). Despite the apparent formation of traces of ammonia from spermidine, we believe that the yeast polyamine oxidase is specific for secondary amino groups.

The data in Table 4 suggest that at least two different mechanisms for sperm(id)ine degradation occur in yeasts, an enzymic attack on the primary amino groups as in P. pastoris, $C$. steatolytica and Sporopachydermia cereana, or an enzymic attack on the secondary amino groups as in $C$. boidinii, C. nagoyaensis, Hansenula polymorpha and Trichosporon melibiosaceum. The enzyme responsible for oxidizing the primary amino groups is maximally active at $\mathrm{pH} 7.0$ and is probably the same as the benzylamine/putrescine oxidase already characterized in $P$. pastoris (Green et al., 1983). The enzyme responsible for oxidizing secondary amino groups is maximally active at $\mathrm{pH} 10.0$ and is, we believe, polyamine oxidase. These two modes of attack do not seem to occur together in one species. 


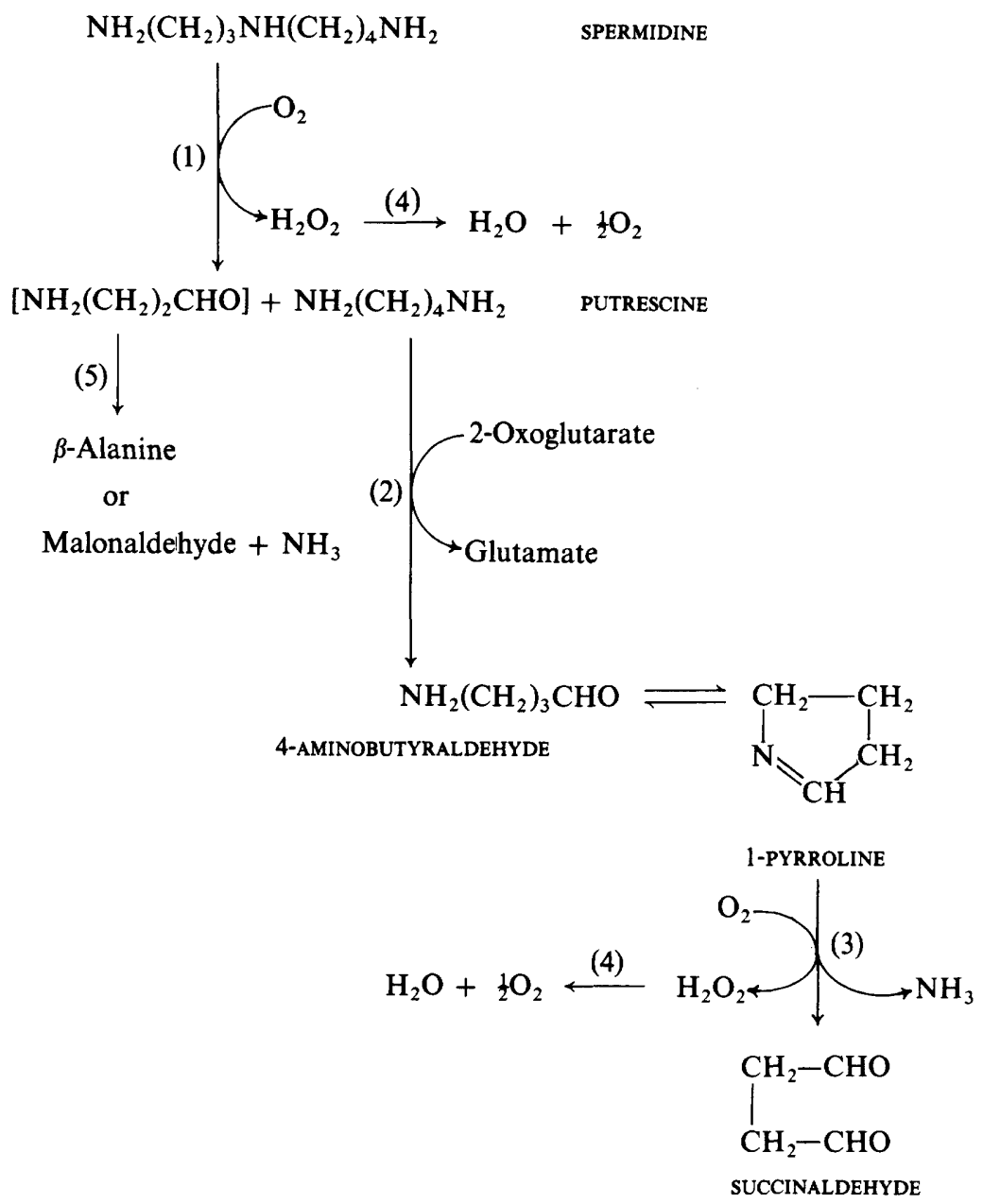

Fig. 4. Suggested pathway for the breakdown of spermidine by Candida boidinii. The enzymes involved are: (1), polyamine oxidase; (2), diamine aminotransferase; (3), benzylamine oxidase; (4), catalase; (5), unknown. The possibility of an additional step involving the $N^{1}$-acetylation of spermidine preceding reaction (1) cannot at this stage be excluded.

We suggest that spermidine and putrescine are degraded by C. boidinii according to Fig. 4 . It is possible that acetylation of the spermidine might precede oxidation, as is thought to occur in mammals (Matsui et al., 1983). Although only low levels of benzylamine oxidase have been found in spermidine-grown cells (Table 4), its behaviour during growth is consistent with its playing a role in spermidine metabolism (Fig. $1 a$ ), while the pattern of methylamine oxidase activity probably is not. Both oxidases have been found to oxidize 1-pyrroline (4aminobutyraldehyde) (G. W. Haywood, unpublished results). The conversion of putrescine to 4aminobutyraldehyde (reaction 2 in Fig. 4) may be a transamination (Tables 3 and 4), because $C$. boidinii, unlike some of the species in Table 4, has no putrescine oxidase activity. In the experiment presented in Figs 1 and 2, putrescine transaminase was elevated in the cells grown on spermidine (results not shown). The fate of the $\mathrm{C}_{3}$ product (probably 3-aminopropionaldehyde) is not certain, but it may be metabolized via either malonaldehyde or $\beta$-alanine. Attempts to show the accumulation of succinaldehyde during growth on spermidine have been unsuccessful. Thus the fate of both the carbon moieties of spermidine remains obscure. It is clear from Fig. $1(a)$ that NAD-linked glutamate dehydrogenase (believed to be involved in yeasts in glutamate degradation: Roon \& Even, 1973; Holzer et al., 1965), may play a significant role in 
the degradation of spermidine, implying that glutamate may be an intermediate in the process, as suggested in Fig. 4. This suggestion is also supported by the data in Table 3.

We previously believed that 4-aminobutyraldehyde (1-pyrroline) was not a substrate for benzylamine oxidase of $P$. pastoris (Green et al., 1983). This conclusion was based on measurements of putrescine oxidation made with benzylamine/putrescine oxidase of $P$. pastoris at concentrations far below the $K_{\mathrm{m}}$ of the enzyme for 1-pyrroline. The enzyme behaved as if only one amino group of putrescine was oxidized. Now that it is clear that at appropriate concentrations 1-pyrroline is indeed a substrate we have an explanation for our observation (Green et al., 1983) that at high putrescine concentrations, more than $1 \mathrm{~mol}$ of ammonia is formed by the Pichia pastoris enzyme per mol putrescine oxidized. 1-Pyrroline is also a substrate for benzylamine oxidase from $C$. boidinii, which, unlike those of $C$. utilis and $P$. pastoris, fails to oxidize putrescine. The postulated roles of benzylamine oxidase (and not of methylamine oxidase) and diamine aminotransferase in the breakdown of spermidine are also supported by the data of Table 3.

\section{REFERENCES}

Albrecht, A. M., Scher, W. I., JR. \& Vogel, H. J. (1962). Determination of aliphatic aldehydes by spectrophotometry. Analytical Chemistry 34, 398400.

ANDREWS, P. (1970). Estimation of molecular size and molecular weights of biological compounds by gel filtration. Methods of Biochemical Analysis 18, 1-53.

BACHRACH, U. \& OsER, I. S. (1963). Enzymatic assay for spermidine. Journal of Biological Chemistry 238, 2098-2101.

BERGMEYer, H. U. (1974) (editor). Methods of Enzymatic Analysis, 2nd English edn pp. 479-480. Weinheim: Verlag-Chemie.

BLAU, K. (1961). Chromatographic methods for the study of amines from biological material. Biochemical Journal 80, 193-200.

Bolkenius, F. N. \& SeIleR, N. (1981). Acetylderivatives as intermediates in polyamine catabolism. International Journal of Biochemistry 13, 287-292.

BRADFORD, M. M. (1976). A rapid and sensitive method for the quantitation of microgram quantities of protein utilizing the principle of protein-dye binding. Analytical Biochemistry 72, 248-254.

Brook, D. F. \& LARGE, P. J. (1976). A steady-state kinetic study of the reaction catalysed by the secondary-amine mono-oxygenase of Pseudomonas aminovorans. Biochemical Journal 157, 197-205.

Chaney, A. L. \& MarbaCh, E. P. (1962). Modified reagents for determination of urea and ammonia. Clinical Chemistry 8, 130-132.

DAvis, B. J. (1964). Disc electrophoresis II. Method and application to human serum proteins. Annals of the New York Academy of Sciences 121, 404-427.

Delaissé, J.-M., Martin, P., Verheyen-Bouvy, M.F. \& NYNS, E.-J. (1981). Subcellular distribution of enzymes in the yeast Saccharomycopsis lipolytica, grown on $n$-hexadecane, with special reference to the $\omega$-hydroxylase. Biochimica et biophysica acta 676, 7790.

Di CoRcia, A. \& SAMPERI, R. (1974). Gas chromatographic determination at the parts-per-million level of aliphatic amines in aqueous solution. Analytical Chemistry 46, 977-981.

DOHERTY, D. (1970). L-Glutamate dehydrogenases (yeast). Methods in Enzymology 17A, 850-856.

EADY, R. R., JARMAN, T. R. \& LARGE, P. J. (1971). Microbial oxidation of amines. Partial purification of a mixed-function secondary-amine oxidase system from Pseudomonas aminovorans that contains an enzymically active cytochrome-P-420-type haemoprotein. Biochemical Journal 125, 449-459.

FERGUSON, K. A. (1964). Starch-gel electrophoresis application to the classification of pituitary proteins and polypeptides. Metabolism 13, 985-1002.

GAHL, W. A. \& Piтot, H. C. (1982). Polyamine degradation in foetal and adult bovine serum. Biochemical Journal 202, 603-611.

Green, J., Haywood, G. W. \& Large, P. J. (1982). More than one amine oxidase is involved in the metabolism by yeasts of primary amines supplied as nitrogen source. Journal of General Microbiology 128 , 991-996.

Green, J., Haywood, G. W. \& Large, P. J. (1983). Serological differences between the multiple amine oxidases of yeasts and comparison of the specificities of the purified enzymes from Candida utilis and Pichia pastoris. Biochemical Journal 211, 481-493.

HAYwOOD, G. W. \& LARGE, P. J. (1981). Microbial oxidation of amines. Distribution, purification and properties of two primary-amine oxidases from the yeast Candida boidinii grown on amines as sole nitrogen source. Biochemical Journal 199, 187-201.

HEDRICK, J. L. \& SMITH, A. J. (1968). Size and charge isomer separation and estimation of molecular weights of proteins by disc gel electrophoresis. Archives of Biochemistry and Biophysics 126, 155-164.

HöltTÄ, E. (1977). Oxidation of spermidine and spermine in rat liver: purification and properties of polyamine oxidase. Biochemistry 16, 91-100.

Holzer, H., Hierholzer, G. \& WiTt, I. (1965). The role of glutamate dehydrogenases in the linkage and regulation of carbohydrate and nitrogen metabolism in yeast. Colloques internationaux du Centre nationale de la recherche scientifique 124, 407-416.

IsOBE, K., TANI, Y. \& YAMADA, H. (1980a). Crystallization and characterization of polyamine oxidase from Penicillium chrysogenum. Agricultural and Biological Chemistry 44, 2651-2658.

Isobe, K., TANI, Y.\& Yamada, H. (1980b). Crystallization and characterization of polyamine oxidase from Aspergillus terreus. Agricultural and Biological Chemistry 44, 2749-2751.

IsOBE, K., TANI, Y. \& Yamada, H. (1980c). Kinetic properties of fungal polyamine oxidases and their 
application to differential determination of spermine and spermidine. Agricultural and Biological Chemistry 44, 2955-2960.

JAKOBY, W. B. (1962). Enzymes of $\gamma$-aminobutyrate metabolism (Bacterial). Methods in Enzymology 5, 765-778.

Jenkins, R. O., Cartledge, T. G. \& Lloyd, D. (1983). Subcellular fractionation of Candida stellatoidea after growth with glucose or $n$-hexadecane. Journal of General Microbiology 129, 1171-1185.

Kawamoto, S., Yamada, T., Tanaka, A. \& Fukui, S. (1979). Distinct subcellular localization of NADlinked and FAD-linked glycerol 3-phosphate dehydrogenases in $n$-alkane-grown Candida tropicalis. FEBS Letters 97, 253-256.

KIM, K. I. (1964). Purification and properties of a diamine $\alpha$-ketoglutarate transaminase from Escherichia coli. Journal of Biological Chemistry 293, 783786.

KIMES, B. W. \& MORRIS, D. R. (1971). Preparation and stability of oxidized polyamines. Biochimica et biophysica acta 228, 223-234.

Kitamura, K., Kaneda, T. \& Yamamoto, Y. (1971). Lysis of viable yeast cells by enzymes of Arthrobacter luteus. Archives of Biochemistry and Biophysics 145, 402-404.

Kobayashi, Y. \& Horikoshi, K. (1981). Production of extracellular polyamine oxidase by Penicillium sp. No. PO-1. Agricultural and Biological Chemistry 45, 2943-2945.

Kobayashi, Y. \& HoRikoshi, K. (1982). Purification and characterization of extracellular polyamine oxidase produced by Penicillium sp. No. PO-1. Biochimica et biophysica acta 705, 133-138.

Kobayashi, Y., Higashi, T., Machida, H., Iwasaki, S. \& HoRIKOSHI, K. (1983). Oxidation of acetylpolyamines by extracellular polyamine oxidase produced by Penicillium sp. No. PO-1. Biochimica et biophysica acta 743, 431-436.

LUNDQUIST, F. (1958). Enzymic determination of acetaldehyde in blood. Biochemical Journal 68, 172177.

MACKLER, B. (1967). DPNH dehydrogenase of yeast. Methods in Enzymology 10, 294-296.

MARTin, R. G. \& AmEs, B. N. (1961). A method for determining the sedimentation behaviour of enzymes: application to protein mixtures. Journal of Biological Chemistry 236, 1372-1379.

Matsui, I., Otani, S., Kuramoto, A., Morisawa, S. \& PEGG, A. E. (1983). Induction of spermidine $N^{1}$ acetyltransferase by sodium $n$-butyrate and phytohaemagglutinin in bovine lymphocytes. Journal of Biochemistry 93, 961-966.

OKada, M., Kawashima, S. \& Imahori, K. (1979). Substrate specificity and reaction mechanism of putrescine oxidase. Journal of Biochemistry 86, 97104.

Osumi, M., Miwa, N., Teranishi, Y., Tanaka, A. \& FUKUI, S. (1975). Development of microbodies in Candida tropicalis during incubation in a $n$ alkane medium. Archives of Microbiology 103, 111.

Robinson, J. \& CoOper, J. M. (1970). Method of determining oxygen concentration in biological media, suitable for calibration of the oxygen electrode. Analytical Biochemistry 33, 390-399.
Roon, R. J. \& Even, H. L. (1973). Regulation of the nicotinamide adenine dinucleotide- and nicotinamide adenine dinucleotide phosphate-dependent glutamate dehydrogenases of Saccharomyces cerevisiae. Journal of Bacteriology 116, 367-372.

SeIler, N., Bolkenius, F. N. \& KNÖDGEN, B. (1980). Acetylation of spermidine in polyamine catabolism. Biochimica et biophysica acta 633, 181-190.

SMITH, T. A. (1972). The physiology of the polyamines and related compounds. Endeavour 31, 22-28.

Suzuki, O., Matsumoto, T., Oya, M. \& Katsumata, Y. (1981). Metabolism of acetylpolyamines by monoamine oxidase, diamine oxidase and polyamine oxidase. Biochimica et biophysica acta 677 , 190-193.

Swain, W. F. \& Dessa, R. J. (1976). Mechanism of action of putrescine oxidase. Binding characteristics of the active site of putrescine oxidase from Micrococcus rubens. Biochimica et biophysica acta 429, 331-341.

TABOR, C. W., TABOR, H. \& BaChraCh, U. (1964). Identification of the aminoaldehydes produced by the oxidation of spermine and spermidine with purified plasma amine oxidase. Journal of Biological Chemistry 239, 2194-2203.

TABOR, H., TABOR, C. W. \& De MeIs, L. (1971). Chemical synthesis of $\mathrm{N}$-Acetyl-1,4-diaminobutane, $N^{1}$-acetylspermidine and $N^{8}$-acetylspermidine. Methods in Enzymology 17B, 829-833.

TOLBERT, N. E. (1981). Metabolic pathways in peroxisomes and glyoxysomes. Annual Review of Biochemistry 50, 133-157.

Von JAGow, G. \& Klingenberg, M. (1970). Pathways of hydrogen in mitochondria of Saccharomyces cerevisiae. European Journal of Biochemistry 12, 583592.

WERNER, W., REY, H.-G. \& Wielinger, H. (1970). Über die Eigenschaften eines neuen Chromogens für die Blutzuckerbestimmung nach der GOD/PODMethode. Fresenius' Zeitschrift für analytische Chemie 252, 224-228.

Wharton, D. C. \& Tzagoloff, A. (1967). Cytochrome oxidase from beef heart mitochondria. Methods in Enzymology 10, 245-250.

Yamada, H., Tanaka, A. \& Ogata, K. (1965). Putrescine oxidase of Micrococcus rubens. Memoirs of the Research Institute for Food Science, Kyoto University, 26, 1-9,

YAMADA, H., IsOBE, K. \& TANI, Y. (1980a). Oxidation of polyamines by fungal enzymes. Agricultural and Biological Chemistry 44, 2469-2476.

Yamada, T., NaWA, H., KaWamoto, S., TANaKa, A. \& FUKUI, S. $(1980 b)$. Subcellular localization of long chain alcohol dehydrogenase and aldehyde dehydrogenase in $n$-alkane-grown Candida tropicalis. Archives of Microbiology 128, 145-151.

ZWART, K. B. (1983). Metabolic significance of microbodies in the yeasts Candida utilis and Hansenula polymorpha. Doctoral thesis, University of Groningen, The Netherlands.

Zwart, K., Veenhuis, M., van DiJken, J. P. \& HARDER, W. (1980). Development of amine-oxidasecontaining peroxisomes in yeasts during growth on glucose in the presence of methylamine as the sole source of nitrogen. Archives of Microbiology 126, 117126. 